Egyptian Journal for Aquaculture

P-ISSN: 2090-7877

E-ISSN: 2636-3984

www.eja.journals.ekb.eg

Elhetawy et al; 2021; 11 (1):41-67

DOI: $10.21608 /$ eia.2021.164670

\title{
Effect of biofloc system at different salinities and crude protein levels on water quality, growth performance, and survival rate of flathead grey mullet (Mugil cephalus).
}

Ashraf. I. G. Elhetawy ${ }^{1}$, Alaa A. El-Dahhar ${ }^{2}$, Elsayed. H Elebiary ${ }^{1}$, Mona A. Abo El-Wafa ${ }^{1}$, Ayman M. Lotfy ${ }^{1}$, Nadezhda Emelianova ${ }^{3}$.

1- Fish Rearing Lab, Aquaculture Division, National Institute of Oceanography and Fisheries (NIOF), Cairo, Egypt.

2- Animal and Fish production Department, Faculty of Agriculture Saba basha Alexandria University.

3- Department of English Philology, Faculty of Foreign Languages, Astrakhan State University, Russian Federation.

Received: March. 25, 2021; Accepted: April.14, 2021 published: 2021 Vol.11 (1):41-67

\section{Abstract}

The present trial was conducted to study the effects of $\mathrm{C} / \mathrm{N}$ ratio to biofloc technology (BFT) at different salinities on water quality, growth performance, and economic feasibility of flathead grey mullet fingerling. BFT was in natural light (12:12h light: dark schedule) with concrete tanks (size $6 \mathrm{~m}^{3}$ water), filled with underground marine and tab water, representing three salinities (fresh, brackish $15.5 \mathrm{ppt}$, and saline $33 p p t)$. Diets contains crude protein $(20 \%, 24 \%)$ were applied under the biofloc system, two levels of $\mathrm{C} / \mathrm{N}$ ratio through adding $60 \%$ starch of the produced daily diet. Two biofloc treatments under different salinity were managed. BFT ponds were aerated and agitated using an air blower. Forty-two fingerlings with an initial body weight of 10.89 $\pm 0.12 \mathrm{~g} /$ fish of grey mullet were stocked in each pond. Feed was applied daily at $3 \%$ of the total fish biomass in each pond. Survival rates of the mullet were above $91 \%$, with a significant $(\mathrm{P} \leq 0.05)$ difference for the brackish water with both $(20 \%, 24 \% \mathrm{CP})$. Regarding growth performances of the grey mullet at the three salinities with $60 \%$ starch, the highest final body weight (FBW), weight gain (WG), and specific growth rate (SGR) values were recorded for fish reared in fresh and brackish water, respectively with no significant differences due to salinities or diets. Water quality parameters alternated between safe values except for nitrate, and no significant $(\mathrm{P}>0.05)$ difference was recorded for zooplankton counts. No significant effects of salinity on the mullet growth were recorded under BFT. 
Keyword: grey mullet, BFT, C/N ratio, different salinities, growth performance.

\section{INTRODUCTION}

With almost nine billion people on earth by 2050, aquaculture is expected to increase 5-fold to face this rising demand and switch from large-scale systems to more intensive systems (FAO 2012, 2016). Aquaculture is an important industry worldwide that provides stable food for the growing world population, with a key role in providing inexpensive and valuable animal protein. The share of aquaculture to the global production of aquatic organisms characterized by a continuous rise, where recorded $25.7 \%$ in 2000, and leapt up to $44.14 \%$ in 2014, then $46.8 \%$ in 2016 with total amount 110.2 million tons, compared to 4\% in 1970 (FAO, 2016, 2018). In Egypt, aquaculture has risen continuously to leap from $15 \%$ in 1995 to $74.18 \%$ in 2012 and record $76 \%$ of the total Egyptian production of fish in 2015 (GAFRD, 2012, 2016).

Recently, due to the negative effects of traditional aquaculture systems, sustainable and innovative farming systems like the BFT system, aquaponic, hydroponics, bioremediation, integrated multi-trophic aquaculture (IMTA), and combined technologies (Elhetawy et al., 2020) have begun to draw the attention of decision-makers in several countries around the world those in the third world (underprivileged) which are experiencing such vital problems as land and water shortage. With the intensification of aquaculture, the focus has significantly shifted to its negative social and environmental impacts. Providing a sustainable development of aquaculture depends upon three fundamental factors. The primary one is that aquaculture expansion should produce more aquaculture products without a significant increase in the use of land and water's core natural resources (Avnimelech, 2009). The second objective is upgrading sustainable aquaculture systems that will not deteriorate the environment (Naylor, et. 2000). The third goal is to establish systems providing a rightful cost/benefit ratio to uphold economic and social sustainability (Avnimelech, 2009; Panigrahi et al., 2019). All the three basic prerequisites mentioned could be achieved using BFT technology.

The basic principle of BFT is the retention of waste and its conversion to heterotrophic bacteria to be used as a natural food within the culture system. This is done by constant aeration and agitation of the water column and the addition of carbon sources as an organic substrate to allow aerobic decomposition and maintain high levels of microbial floc in suspension in fed and/or fertilized ponds (Hargreaves, 2006; Avnimelech and Kochba, 2009). Theoretically, the increased $\mathrm{C} / \mathrm{N}$ ratio through carbon addition enhances the conversion of toxic inorganic nitrogen species to microbial biomass available as food for culture animals. The optimum $\mathrm{C} / \mathrm{N}$ ratio in an aquaculture system 
can be maintained by adding different locally available cheap carbon sources and/or reducing protein content in the feed (Naik and Reddy, 2020).

These BFT systems rely on the living microorganisms in the biofloc (composed of microbial biomass and particulate organic matter) maintained in the water column to assist in ammonia removal via phytoplankton, bacterial uptake, bacterial oxidation of ammonia- $\mathrm{N}\left(\mathrm{NH}_{3}-\mathrm{N}\right)$ to nitrite- $\mathrm{N}\left(\mathrm{NO}_{2}-\mathrm{N}\right)$, and then subsequent oxidation of $\mathrm{NO}_{2}-\mathrm{N}$ to nitrate- $\mathrm{N}\left(\mathrm{NO}_{3}-\mathrm{N}\right)$ during nitrification (Ebeling et al., 2006; Manan et al., 2020). Therefore, these biological processes play a critical role in reducing ammonia and nitrite to levels below those that can be toxic or growth-limiting for cultured mullet fish.

Mullet is one of the most popular fish groups in Egypt, and it is the second after tilapia among the main farmed species. The production of farmed mullet reached 213,980 metric tonnes representing about $30.33 \%$ of the total production of farmed fish (Essa, 2010). The flathead grey mullet Mugil cephalus and the thinlip grey mullet, Liza ramada, constitute most of the harvest of mullet in Egypt. The availability and abundance of the wild fry of these species as compared to those of Chelon labrosus, Oedalechilus labeo, Liza aurata, Liza abu, Liza saliens, and Liza carinata, make it the dominant aquacultural species (Saleh, 2008). Thus, this experiment was conducted to evaluate the growth performance, survival rate, water quality, and economic feasibility of Mugil cephalus grown under BFT at different salinities.

\section{MATERIAL AND METHODS}

\section{Experimental location and duration}

The present experiment was carried out in El-Max Research Station, National Institute of Oceanography and Fisheries (NIOF), Alexandria Governorate, Egypt, and continued for 70 days.

\section{Ponds and experimental design}

Eighteen concrete tanks $(6 \mathrm{~m} 3$ each) under a tent act as a cover in a $(2 \times 3)$ factorial design were used. Each pond was inoculated by clay from another tilapia fishpond, and some of the water from draining canal as a source of inoculation along with $50 \mathrm{gm}$ Urea as a source of nitrogen. Ponds were representing six experimental treatments in triplicate, where two crude protein levels $(20 \%$, and $24 \%$ ), and three water salinities (underground marine water $33 \mathrm{ppt}$ (part per thousand), brackish water with a salinity of $15 \mathrm{ppt}$, and freshwater (tab water), were used to study the effect of biofloc system under deferent salinities on the flathead grey mullet growth performance, and water criteria as shown in Table 1.

\section{Fish and rearing techniques}

Flathead grey mullet fingerlings with an initial body weight of $10.89 \pm 0.12$ g/fish were obtained from Rashid region, Elbehira Governorate, Egypt. On 
August $1^{\text {st }}$, fish were acclimatized to the new water conditions for two weeks and fed a diet containing ( $24 \% \mathrm{CP})$. Fingerlings were stocked at a $42 \mathrm{fish} /$ pond $\left(7 \mathrm{fish} / \mathrm{m}^{3}\right.$ ), representing six experimental treatments in triplicate. Fish were held under natural light (12:12 h, light: dark schedule). The water level was maintained at approximately $6 \mathrm{~m}^{3}$, and water loss due to evaporation and leakage was replaced whenever necessary according to water size in BFT ponds. Aeration and agitation were continuously provided using an air blower.

\section{Diets formation and preparation}

The two experimental diets were formulated from fish meal, soybean meal, yellow corn, wheat bran, wheat flour, carboxymethylcellulose (CMC), ascorbic acid, fish oil, vitamins, and minerals mixture. Ingredients were obtained from the local market in Egypt. The dry ingredients were mixed thoroughly at first and with oil after that. The experimental diets were pelleted, all diets were put into sacks after samples had been taken and stored at $-20^{\circ} \mathrm{C}$ in a deep freezer until use. The composition (\%) and chemical analysis (\% dry matter bases) of experimental diets are presented in (Table 2)

\section{Feeding regime}

Fish were fed with an experimental diet ( $20 \%$ and $24 \%$ CP) under a biofloc system using $60 \%$ starch of the daily diet. The proportions of protein used in this experiment and the amount of starch were tested at a previous trial carried out in 2013 by El-Dahhar et al. (2015). The daily ratio was 3\% of the total stocked biomass divided into two equal amounts and offered at (9.00 AM and $2.00 \mathrm{PM})$. To adjust the feed amount, fish in each replicate pond were weighed every 15 days and then returned to the ponds.

\section{Water criteria:}

Water quality parameters were monitored daily during the study period. Temperature and $\mathrm{pH}$ values of the water samples were measured in the field using a graduating thermometer and portable digital $\mathrm{pH}$ meter (Model 201/digital). Water salinity and total dissolved solids (TDS) were measured using Salinometer (Bekman, Model RS-10). Dissolved oxygen was measured using oxygen meter model Hanna oxy check. Organic phosphors were measured by seal AA3 auto analyzer. Ammonia, nitrite, and nitrate were measured weekly and calorimetrically measured using (Ammonia $\mathrm{NH}+4 / \mathrm{NH}_{3}$, Nitrite $\mathrm{NO}_{2}$, and Nitrate) rapid test for water quality. All tests are prepared, quality controlled, and assured by staff members of the Biomedical Chemistry Unite according to the ISO/IEC 17025, 6353, 5664, and 71501. All rights reserved to the Animal Health Research Institute (AHRI), Agricultural Research Center (ARC), and Ministry of agriculture -land Reclamation, Egypt. 
Table (1): design of two dietary protein levels with three water salinity levels without water exchange using $60 \%$ starch of daily diet.

\begin{tabular}{lc}
\hline Crud protein and 60\% Starch & Water Salinity(ppt) \\
\hline \multirow{2}{*}{$20 \%(\mathrm{C} / \mathrm{N}, 19: 1)$} & $33(\mathrm{~m})$ \\
\cline { 2 - 2 } & $15(\mathrm{~b})$ \\
\hline \multirow{2}{*}{$24 \%(\mathrm{C} / \mathrm{N}, 16: 1)$} & $1>(\mathrm{f})$ \\
\cline { 2 - 2 } & $33(\mathrm{~m})$ \\
\hline
\end{tabular}

Where: (m): marine, (b): brackish, (f): fresh

Table (2). Formula and chemical analysis (\%) of the experimental diets.

\begin{tabular}{lcc}
\hline Ingredients & $20 \% \mathrm{CP}$ & $24 \% \mathrm{CP}$ \\
\hline wheat flour & 25.80 & 20.00 \\
wheat bran & 23.40 & 21.20 \\
Soya bean meal & 7.00 & 10.00 \\
Yellow corn & 21.40 & 20.70 \\
fish meal & 14.00 & 20.00 \\
Fish oil & 4.80 & 4.50 \\
CMC1 & 3.00 & 3.00 \\
Vit, Min, Mix 2 & 0.40 & 0.40 \\
Ascorbic acid & 0.20 & 0.20 \\
Proximate composition (\%) & & \\
Dry matter (\%) & 88.40 & 88.40 \\
Protein (\%) & 20.05 & 24.05 \\
Lipid (\%) & 10.47 & 9.66 \\
Total carbohydrate (\%) 3 & 61.06 & 55.25 \\
Ash (\%) & 5.55 & 7.91 \\
Gross energy (kcal/kg) 4 & 464.7 & 455.93 \\
Protein energy & 43.14 & 52.75 \\
ratio(mgCP/kcal) & & \\
\hline
\end{tabular}

(1) CMC: Carboxy methyl cellulose

(2) Vitamins and minerals mixture: Each 1 kg contains Vit A (400000 i.u.), Vit D (100000 i.u.), Vit E (250 mg,) Vit K3 (200 mg,) Vit B1 (200 mg), Vit B2 70mg, Vit B6 (200mg), Vit B12 (1mg), Vit C 450mg, Niacin 1000mg, Methionine1000mg, Cholin chloride 10000mg, Folic acid 100mg, Biotin 2mg, Panthonic acid 220mg, Magnesium sulphate 1000mg, Copper sulphate $1000 \mathrm{mg}$, Iron sulphate $3000 \mathrm{mg}$, Zinc sulphate , 600mg, Cobalt sulphate $100 \mathrm{mg}$, Carrier upto $1000 \mathrm{mg}$.

(3) Total carbohydrate $=100-(\mathrm{CP}+\mathrm{EE}+\mathrm{Ash})$

(4) Gross energy (GE) was calculated as 5.64, 9.44 and $4.11 \mathrm{kcal} / \mathrm{g}$ for protein, lipid and NFE, respectively NRC, (1993). 


\section{Initiation of biofloc:}

All treatments were biofloc at different salinities. Starch is added at one level $(60 \%)$ of the feed intake to maintain the recommended $\mathrm{C} / \mathrm{N}$ ratio (> N1: C10) to stimulate the growth of heterotrophic bacteria. Starch was dissolved in water at a plastic tank and spread over the pond surfaces at (10 AM), whereas the microbiota used to inoculate the ponds was obtained from a tilapia fish farm.

\section{Fish sampling}

To adjust the feed amount, fish in each triplicate were weighted to the nearest 0.00 every 15 days, as they were transferred to a tank containing water from the trial ponds, then returned to ponds after measuring their weights.

\section{Growth performances}

Weight gain $(\mathrm{WG})=\mathrm{W} 2-\mathrm{W} 1$.

Where: $\mathrm{W} 1=$ Initial body weight $(\mathrm{g})$ and $\mathrm{W} 2=$ Final body weight $(\mathrm{g})$.

Specific growth rate $(\%)(\mathrm{SGR})=[(\mathrm{LnW} 1-\mathrm{LnW} 0) \div \mathrm{T}] \times 100$.

Where: $\mathrm{Ln}=$ Natural $\log , \mathrm{W} 0=$ Initial body weight $(\mathrm{g}), \mathrm{W} 1=$ Final body weight $(\mathrm{g})$ and $\mathrm{T}=$ Time (day).

\section{Feed utilization parameters}

Feed conversion ratio $(\mathrm{FCR})=$ feed intake $(\mathrm{g}) /$ body weight gain $(\mathrm{g})$.

Protein efficiency ratio $(\mathrm{PER})=$ gain in weight $(\mathrm{g}) /$ protein intake in feed $(\mathrm{g})$. Condition factor $(\mathrm{K})=$ weight $/$ length ${ }^{3} \times 100$

Fish survival $(\%)=100$ (final fish number/initial fish number).

\section{Chemical analysis of fish and diets}

At the beginning and the end of the trial, random pooled fish samples were collected and sacrificed to determine the initial whole-body proximate composition. Fish samples were oven-dried at $65^{\circ} \mathrm{C}$, ground, and stored at $20^{\circ} \mathrm{C}$ for subsequent analysis. The chemical composition of fish samples was determined according to the procedures of AOAC (1995). Dry matter was determined after drying the samples in an oven $\left(65^{\circ} \mathrm{C}\right)$ for $24 \mathrm{~h}$. Ash by incineration at $\left(550^{\circ} \mathrm{C}\right)$ for $12 \mathrm{~h}$, crude protein was determined by microKjeldahl method, $\% \mathrm{~N} \times 6.25$ (using Kjeltech autoanalyzer, Model 1030, Tecator, Hoganas, Sweden), and crude fat by Soxhlet extraction with petroleum ether $\left(60-80^{\circ} \mathrm{C}\right)$. The chemical analysis of the experimental diets used in the experiment was done according to AOAC (2000).

\section{Counting and identification of biofloc community}

Direct manual quantification of total bacteria was carried out to determine the total bacterial counts. Composite water samples ( $1 \mathrm{~L}$ per tank) were collected biweekly, beginning at 8-11 AM, and through 1-4 PM, by combining 
four $250-\mathrm{mL}$ samples obtained approximately $15 \mathrm{~cm}$ below the water surface and from the middle of each side of the pond. Formalin $(40 \mathrm{~mL})$ was added to each 1 liter of the sampling water in a numbering flask to aggregate algae, zooplankton, and microorganisms. Then, every water sample was filtered through plankton net $55 \mu$ mesh size, $25 \mathrm{~cm}$ diameter and $50 \mathrm{~cm}$ length, of aggregated algae volume. All microorganisms were measured by a numbering tube $(0.5-50) \mathrm{ml}$ graduation as an alternative to Imhoff cones. Identification was conducted by transferring a $1-\mathrm{mL}$ sample into a microbiology laboratory and using a binocular research microscope (150×magnification). Also, identifying algae and micro-organisms was made according to the following references: (Paerl and Tucker, 1995; Prescott, 1962; foissner and Berger, 1996; Wallace and snell, 1991; Pontin, 1978).

\section{Statistical analysis}

Statistical analysis was carried out using the analysis of variance (ANOVA) two-way classification and Duncan's Multiple Range Test (Dunkan, 1955) to determine differences between treatment means at a significant rate of $\mathrm{P} \leq 0.05$. The standard errors of means were also estimated. The ANOVA test was performed using SPSS software program, Version 22.

\section{Economic efficiency and evaluation}

The descriptive-analytical and economical style was used during the present experiments to study and explore the key economic features of flathead grey mullet culture under BFT conditions, according to Helal and Essa (2005). Also, some evaluating performance parameters were used to identify the current operating economics of culture flathead grey mullet according to Abdel Hafez and El - Kariony (1992) as well as Scott $\boldsymbol{e t}$ al. (1993), such as: Operating ratio $(\%)=$ Total operational costs/Revenue

1. Return on sales $(\%)=$ Net income/Revenue

2. Return on costs $(\%)=$ Revenue/Total operational costs

3. Capital recovery period (years) $=$ Investments/Annual income

4. Return on equity $(\%)=$ Net income/Investments

5. Rate of return as a $\%$ of total inputs $=$ Net income $/$ Total operation costs Data of all the fixed and variable costs and depreciation of capital and the outputs of farmed fish, and price of sale and revenue, were collected during the present study period.

\section{RESULTS AND DISCUSSION}

\section{Water quality criteria}

The differences among the treatments in water quality parameters are shown in (Table 3). Generally, the average water temperature during the experimental period ranged between $\left(17.5-25.3^{\mathrm{c}}\right)$, while $\mathrm{pH}$ ranged (8.31-9.0), salinity 
ranged (0.4- 41.5) ppt, dissolved oxygen ranged (5.5-6.6) ppm, total dissolved solids (TDS) ranged (0.445-35.8) g/l, and organic phosphors ranged (0.06-1.1) ppm. Besides, the recorded values of total ammonia nitrogen (TAN), which were used in calculating unionized ammonia $\left(\mathrm{NH}_{3}\right)$ changed numerically within the normal range $(0.5-2 \mathrm{mg} / \mathrm{l})$ under different salinities. In the same context, a normal range of nitrite $\left(\mathrm{NO}_{2}\right)(<0.5 \mathrm{mg} / \mathrm{l})$ was observed for all treatments during the experimental period (Fig, 1). The nitrate $\mathrm{NO}_{3}$ was noticed higher than the normal range $(5 \mathrm{mg} / \mathrm{l})$ in all treatments during the experimental period (Fig. 2).

These results indicated that there were significant differences in water parameter, total dissolved solid TDS, dissolved oxygen $\mathrm{DO}, \mathrm{pH}$, and organic phosphors due to different salinities. No significant difference in water temperature. By referring to the output of nitrogen TAN, $\mathrm{NO} 2$, and $\mathrm{NO}_{3}$ there is no significant difference due to salinity under BFT conditions. Still, the treatments ( 24 and $20 \% \mathrm{CP}$ ) with $60 \%$ starch in freshwater recorded the lowest measurements.

The growth of euryhaline species such as flathead grey mullet is often affected by salinity because the energy used for osmoregulation is not available for growth (Brett, 1979; Wootton, 1990). Consequently, many of these species have an optimal salinity level. The growth rate is highest and the cost of osmoregulation lowest, which may affect fish distribution in the wild (Bartholomew and Kevin, 2013). Although mullets are classified as marine fish and always spawn at sea, they are highly euryhaline and thrive in a wide range of salinities (McDowall, 1988). Due to their euryhalinity, they are often stocked in brackish coastal lagoons to improve fish yield. They are introduced into freshwater lakes and reservoirs to create new fisheries (Ben Tuvia et al., 1992), so in this experiment, salinity was never a problem for mullet.

In this experiment, the application of BFT technology in mullet culture under three different levels of salinity offered a solution (allowed) to avoid the environmental impact of high nutrient discharges and excess nutrients converted into microbial biomass, which was controlled in water criteria. We noticed that all ponds characterized no transparent because of their high turbidity and noticed no differences in water quality under BFT system due to salinity, especially $\mathrm{pH}, \mathrm{DO}$, and nitrogen contents, which had no significant differences among (fresh, brackish, and marine water). Significant differences were observed in TDS and organic phosphors among the three levels of salinity due to the use of tap water which has a slim content of TDS, and organic phosphors in two treatments (freshwater < 1ppt) and (brackish water 14-17ppt) to reduce salinity in brackish water ponds, but all measurements were in safe levels for fish. In contrast, Azim et al.(2008) recorded similar results for inorganic nitrogen (TAN, $\mathrm{NO}_{2}-\mathrm{N}$, and $\mathrm{NO}_{3}-\mathrm{N}$ ) concentrations and dissolved oxygen throughout the experimental period which had been implemented on 
Nile tilapia indoor tanks. However, in contradiction with us, they recorded a decrease in $\mathrm{PH}$ values throughout the experimental period.

Table (3). Difference in water quality parameters status in the second experiment between different salinities (marine, brackish, and fresh) water under $20 \%$ and $24 \% \mathrm{CP}$ with $60 \%$ starch.

\begin{tabular}{|c|c|c|c|}
\hline \multirow[b]{2}{*}{ Items } & \multicolumn{3}{|c|}{ Concrete ponds } \\
\hline & $\begin{array}{c}\text { Marine water } \\
\text { ponds under } \\
\text { BFT system } \\
\text { with } 20,24 \% \mathrm{CP} \\
\text { and } 60 \% \text { starch }\end{array}$ & $\begin{array}{c}\text { Brackish water } \\
\text { ponds under } \\
\text { BFT system } \\
\text { with } 20,24 \% \mathrm{CP} \\
\text { and } 60 \% \text { starch }\end{array}$ & $\begin{array}{c}\text { Fresh water } \\
\text { ponds under } \\
\text { BFT system } \\
\text { with } 20,24 \% \mathrm{CP} \\
\text { and } 60 \% \text { starch }\end{array}$ \\
\hline Temperature $\left({ }^{\circ} \mathrm{C}\right)$ & $18-25.3^{\mathrm{c}}$ & $17.9-24.8^{\mathrm{c}}$ & $17.5-24.8^{\mathrm{c}}$ \\
\hline Salinity $(\mathrm{mg} / \mathrm{l})$ & $31.9-41.5$ & $14-17$ & $0.4-0.642$ \\
\hline $\mathrm{pH}$ & $8.40-8.77$ & $8.31-8.70$ & $8.79-9.09$ \\
\hline $\mathrm{TDS}(\mathrm{g} / \mathrm{l})$ & $33.21-41.89$ & $16.59-19.76$ & $0.445-0.695$ \\
\hline Organic phosphors(ppm) & $0.7-1.1$ & $0.57-1.2$ & $0.07-0.44$ \\
\hline $\mathrm{DO}(\mathrm{mg} / \mathrm{l})$ & $5.5-6.2$ & $5.7-6.3$ & $5.9-6.6$ \\
\hline Total ammonia nitrogen (TAN) ppm & $0.1-0.4$ & $0.12-0.38$ & $0.07-0.38$ \\
\hline Nitrogen nitrite $\left(\mathrm{NO}_{2}\right) \mathrm{ppm}$ & $0.00-0.22$ & $0.00-0.18$ & $0.00-0.16$ \\
\hline Nitrogen nitrate $\left(\mathrm{NO}_{3}\right) \mathrm{ppm}$ & $2-9$ & $2-9$ & $1-10$ \\
\hline
\end{tabular}

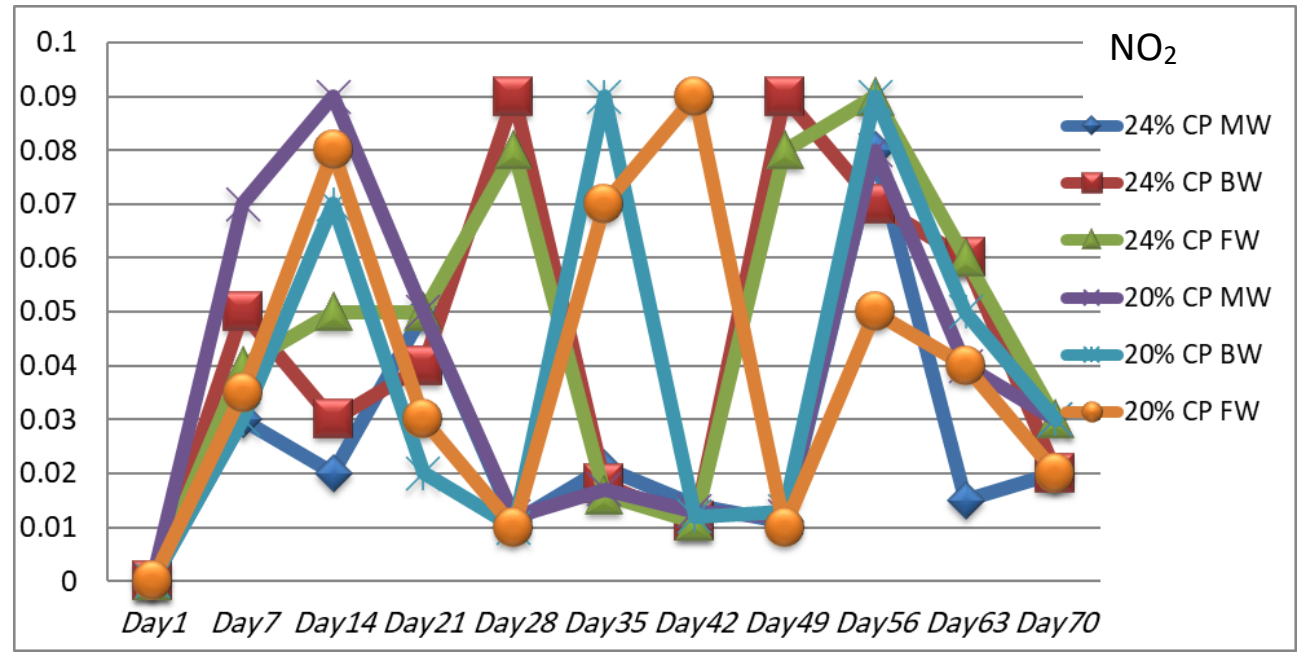

Fig. (1). Total nitrogen nitrite (NO2) values for biofloc treatments under different Salinities with $(24 \%, 20 \% \mathrm{CP}$, and $60 \%$ starch $)$. 


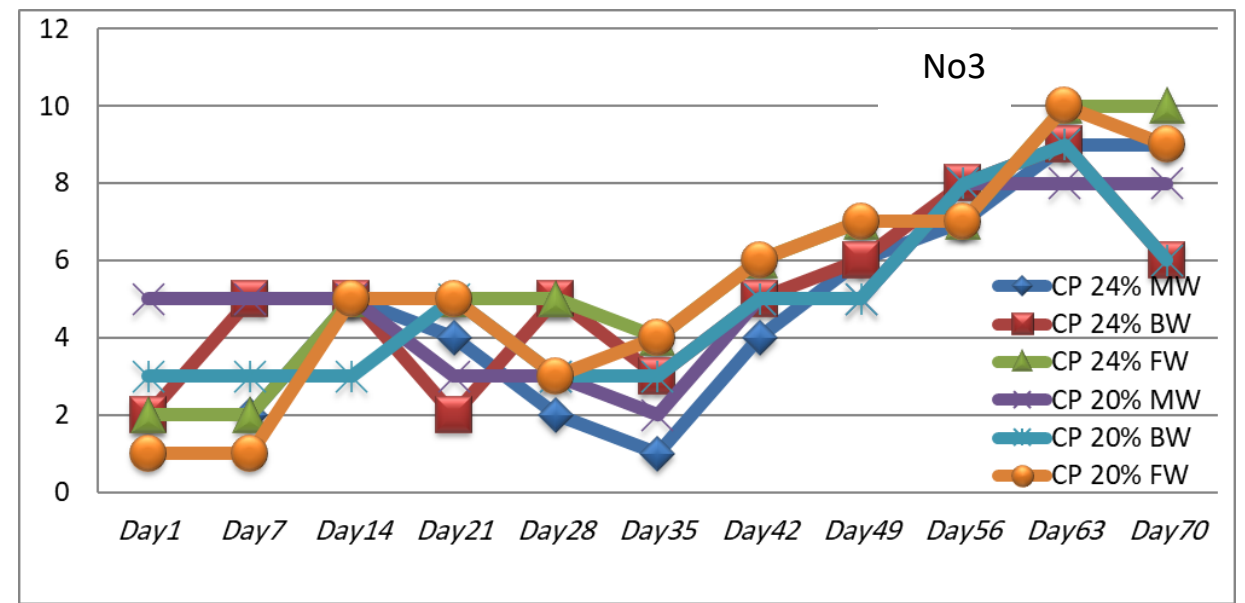

Fig. (2). Total nitrogen nitrate values for biofloc treatments under different Salinities with (24\%, 20\% CP, and 60\%starch), where (MW): marine water, (B W): brackish water, (F W): fresh water. (CP): crude protein.

Also, the results were recorded close to water parameters ( $\mathrm{pH}, \mathrm{DO}, \mathrm{TAN}$ and $\mathrm{NO}_{2}-\mathrm{N}$ ) by Braga et al. (2013) when they designed an experiment for the production of litopenaeus vannamei in biofloc-dominated zero-exchange raceways (RWs) by using a mixture of fresh and sea water. They added freshwater weekly to maintain salinity, and RWs were maintained with no water exchange. Mean water temperature, salinity, DO, and $\mathrm{pH}$ were $29.6 \mathrm{oC}$, $29.3 \mathrm{ppt}, 5.5 \mathrm{mg} / \mathrm{l}$, and 7.1, respectively. Mean TAN and $\mathrm{NO}_{2}-\mathrm{N}$ were $<0.4$ $\mathrm{mg} / \mathrm{l}$, and final $\mathrm{NO}_{3}-\mathrm{N}$ levels averaged $309 \mathrm{mg} / \mathrm{l}$. Mean TSS and SS levels were $292 \mathrm{mg} / \mathrm{l}$ and $12 \mathrm{ml} / \mathrm{l}$, respectively.

\section{Phytoplankton and zooplankton count:}

Direct manual quantification of total bacteria was carried out to determine the total bacterial counts, and the observations were recorded as follows. All biofloc treatments under fresh, brackish, and marine water had gradually increased in floc volume through the seventy days of the experiment. No significant differences among treatments in floc volume, but the high floc volume was obtained from biofloc treatments $(20 \% \mathrm{CP}$ with $60 \%$ starch, and $24 \% \mathrm{CP}$ with $60 \%$ starch) under freshwater $(20 \% \mathrm{CP}$ with $60 \%$ starch and $24 \% \mathrm{CP}$ with $60 \%$ starch) under brackish water, and (20\% CP with $60 \%$ starch, $24 \% \mathrm{CP}$ with $60 \%$ starch) under marine water respectively. The absence of a significant difference between treatments is due to the possibility of growth for biofloc organisms in any salinity in case of balance in $\mathrm{C} / \mathrm{N}$ ratio. 
Table: (4): Zooplankton and phytoplankton count and species identification in experimental treatments with dietary crude protein levels (24, 20 with $60 \%$ starch) under different salinities (fresh, brackish, and marine water).

\begin{tabular}{|c|c|c|c|c|c|c|c|c|c|}
\hline & & & Syste & em cond & ditions an & nd count & ( natural u & unit/ml) & 20/60F.W \\
\hline Division & Genus or sp & cies & & & & 4/60F.W 2 & & 20/60B.W & $20 / 60 \mathrm{~F} . \mathrm{W}$ \\
\hline Chlorophyta & Ankistrod & esmus sp. & & 5500 & 9000 & 180000 & 5000 & 45000 & 190000 \\
\hline & Gloeocysti & $s p$. & & 0000 & 12000 & 22000 & 15000 & 5000 & 23000 \\
\hline & Scenedesm & us sp. & & 4000 & 5000 & 9000 & 0 & 5000 & 13000 \\
\hline Copepoda & copepotid & e sp. & & 1000 & 13000 & 55400 & 5000 & 20000 & 150000 \\
\hline Rotifera & Brachinou & plicatilis & & 3000 & 17000 & 0 & 8000 & 21000 & 0 \\
\hline & paramecium & sp. & & 9000 & 49000 & 31000 & 14000 & & 40000 \\
\hline & Euchlanis st & & & 2000 & 36000 & 29000 & 108000 & & 0 \\
\hline Colt & Iurellaadriatic & a(Ehrenber & & $\mathbf{0}$ & 1300 & 2500 & 1000 & 3000 & 4000 \\
\hline & Colurellaobtu & sa(Gosse) & & 0 & 1000 & 2000 & 0 & & 0 \\
\hline & Cephalodellas & & & 1000 & 3000 & 50000 & 0 & 4000 & 6000 \\
\hline Tokopl & hyraquadripa & rtita(Good & & $\mathbf{0}$ & 0 & 10000 & 1000 & & 9000 \\
\hline & richocerca s| & & & 8000 & 90000 & 62000 & 19000 & 3000 & 22000 \\
\hline Cyanophyta & Coelospha & erium sp. & & 3100 & 0 & 0 & 1000 & & 0 \\
\hline Bacillariophyta & Centric o & iatoms & & 0 & 0 & 0 & 3000 & & 0 \\
\hline & Pennate $d i$ & atoms & & 5000 & 35000 & 27000 & 14000 & 6000 & 29000 \\
\hline Euglenophyta & Trachelon & lonas sp. & & 6000 & 8000 & 6000 & 4500 & 3200 & 4000 \\
\hline & Phacus sp. & & & 3000 & 7000 & 9000 & 0 & & 0 \\
\hline Diatomes & Chaetocer & & & 0000 & 65000 & 0 & 29000 & 12000 & 0 \\
\hline & Liptocylind & & & 1000 & 99000 & 1000 & 9000 & 2000 & 50000 \\
\hline & Melosira & & & 2000 & 81000 & 63000 & 17000 & & 4000 \\
\hline & Rhzosolenia & & & 5000 & 24000 & 14000 & 12000 & 4000 & $\mathbf{0}$ \\
\hline Protozoa & Arcella vulg & aris & & 1000 & 0 & 2000 & 0 & 4000 & 0 \\
\hline & Didiniumsp. & & & 0 & 1000 & 1000 & 1000 & 500 & 0 \\
\hline & Difflugia cor & na(Bovee) & & 0 & 0 & 0 & 6000 & & 6000 \\
\hline Vortice & ella campanu & la(Ehrenbe & & 2000 & 65000 & 45000 & 70000 & 50000 & 110000 \\
\hline & Centropyxioc & uleatea & & 4000 & 6000 & 5000 & 5000 & 15000 & 1000 \\
\hline & Lepadellaova & is(O.F.Mul & & $\mathbf{0}$ & 45500 & 140000 & 5000 & & 150000 \\
\hline & Philodena sp. & & & 0 & 23000 & 150000 & 0 & 62000 & 175000 \\
\hline Micr & Igae & & & & & & & & \\
\hline & etraselmis te & rathele & & 000018 & 180000 & 0 & 287000 & 246000 & \\
\hline & keletonema c & ostatum & 450 & 000011 & 110000 & 0 & 316000 & 475000 & 0 \\
\hline Total count & & & 985 & 560098 & 985800 . & 985900 & 985500 & 985700 & 986000 \\
\hline pooled means & $C$ & $C_{c}$ & Ro & $C y$ & $\mathrm{Ba}$ & $E u$ & $D i$ & $\operatorname{Pr}$ & $M G A$ \\
\hline 24 & 88833.3333 & 23133 & 145600 & 1033 & 22333 & 13000 & 168333 & 203500 & 320000 \\
\hline 20 & 100333.333 & 58333 & 87667 & 333.33 & \begin{tabular}{l|l}
3 & 17333
\end{tabular} & 3900 & 56333.3 & 220167 & 441333.33 \\
\hline M W & 24750 & 3000 & 104500 & 2050 & 1500 & 6750 & 92500 & 107000 & 636500 \\
\hline B W & 40500 & 16500 & 114150 & 0 & 0 & 9100 & 131500 & 134000 & 505500 \\
\hline F W & 218500 & 102700 & 128750 & 0 & 0 & 9500 & 101000 & 264500 & 0 \\
\hline
\end{tabular}

Where: (Mw) marine water, $(\mathrm{Bw})$ brackish water, $(\mathrm{Fw})$ fresh water, $(\mathrm{Ch})$ Chlorophyta, Ro (Rotifer), Co (Copepod), Cy (Cyanophyta), Ba (Bacillariophyta), Eu (Euglenophyta), Pr (Protozoa), Di (Diatomes), MGA (Micro green algae).

Also, the other second sub-sample $(50 \mathrm{~mL})$ which was removed from the original composite water sample that was collected from each pond, had been analyzed, in the microbiology laboratory in the Faculty of Veterinary Medicine using a binocular research microscope with $(150 \times$ magnification $)$, to identify and enumerate algae, zooplankton, and all microorganisms. The microscopic 
evaluation which had been performed to the pond water revealed the presence of several species of diatoms, Chlorophyta, Rotifer, Copepod, Cyanophyta, Bacillariophyta, Euglenophyta, Protozoa, Microgreen algae, presented in Table (4). No undesirable species of cyanobacteria (e.g., colonial such as potential toxin-producing Microcystis spp. or filamentous types such as $P$. perornata) were observed to be present in the pond water.

The identification and enumeration of the species in different experimental treatments are presented in Table (4). As described in this table, the highest total account of phytoplankton and zooplankton was recorded for $(20 \% \mathrm{CP}$ with $60 \%$ starch) under freshwater. In contrast, no significant differences were recorded among the treatments in floc enumeration but some species such as Rotifer Brachinous plicatilis, and microgreen algae species Skeletonema Costatum, Tetrathelmis Tetrathele existed in marine and brackish water but were not seen in freshwater. The species of Cyanophyta Coelosphaerium sp. and Bacillariophyta Centric diatoms existed in marine but were not seen in fresh water and brackish water. Also, in this table, we noticed that increasing protein levels with different salinities did not cause any increase in final floc enumeration.

In this trial, the identification and enumeration of the species are in agreement with Schrader et al. (2011), who cited that the microscopic evaluation of the pond water which was performed revealed the presence of several species of diatoms (division Bacillariophyta) and green algae (division Chlorophyta) including chlorophytes in the following genera: Ankistrodesmus, Chlamydomonas, Closterium, Quadrigula, and Selenastrum, and he did not notice undesirable species of Cyanobacteria (e.g., colonial such as potential toxin-producing Microcystis spp. or filamentous types such as $P$. perornata) which observed to be present in the pond water. Also, Souady (2013) confirmed the species of Lepadellaovalis (O.F.Muller), Monostyllaclosterocerca (Schmarda), Philodenasp, Rotifer Genus, including Trichoceraca sp. Colurellaadriatica(Ehrenberg), Colurellaobtusa(Gosse), Trichocerca sp. Cephalodella sp. Euchlannis sp. Paramecium sp. Tokophyraquadripartita(Goodrich\& Jahn). Protozoa group including Vorticella campanula (Ehrenberg), Centropyxisoculeatea(Stein.), Arcella vulgaris(Ehrenberg), Difflugia corona(Bove) Didinium sp. And group copepod, including Copepotidae.

In addition to that, an increase in the feed intake of fish reared in fresh water, and brackish water with the two levels of protein which elevated by the fish output (feces) was noticed, and in the presence of starch, a suitable environment for microorganisms(biofloc) and zooplankton growth was established. Meanwhile, the active growth of biofloc under these conditions exceeds the fish ability of consumption. Carb (2010) concluded that the 
biological flocs could be considered a kind of a fast-growing microbial mixed culture in which the waste nitrogen is recycled to young cells, which subsequently are grazed by the fish.

\section{Mullet growth performance}

Growth performances for flathead grey Mullet (Mugil cephalus) reared in three salinities (freshwater $<1 \mathrm{ppt}$, brackish water 14-17 ppt, and marine water >30ppt) under (BFT) conditions (C/N 19:1) and (C/N 16:1), feeding on two diets $20 \%$ and $24 \% \mathrm{CP}$ with $60 \%$ starch are presented in Table (5). The results in this table showed that a significant difference in mullet growth performances was recognized for the benefit of both fresh and brackish water, where the highest final body weight (FBW), weight gain (WG), and specific growth rate (SGR) values recorded for fish reared in fresh and brackish water respectively with no significant differences due to salinities or diets. Then marine water came recording a significant decrease compared to freshwater without brackish water.

Although there were no significant differences between fresh and brackish water, freshwater showed little superiority over brackish, and significantly outweighed marine water in all growth performance parameters of fish fed both protein levels. Regarding interaction results, fish fed (20\% CP with 60\% starch) under freshwater BFT system demonstrated the highest FBW, WG, and SGR, but the lowest results were noticed for $(24 \%$ CP and $20 \%$ CP with $60 \%$ starch) under marine water BFT system.

These results agree with the finding of Cardona, (2000) who conducted a laboratory experiments and revealed that the metabolic rate of Mediterranean flathead grey Mullet (Mugil cephalus) young specimens was negatively affected by high salinity levels and that an improved growth performance was achieved in freshwater and oligohaline water. Also, he demonstrated that through a stratified study on microhabitat use, which was carried out on the island of Minorca (Balearic archipelago), juvenile specimens, shorter than 200 $\mathrm{mm}$ (total length), concentrated all year round in freshwater or oligohaline sites. Mesohaline areas were usually avoided, except in summer. With a total length between 201 and $300 \mathrm{~mm}$, immature fish show a similar pattern while in some seasons avoided freshwater sites. The habitat selection pattern of adults, i.e., fish longer than $301 \mathrm{~mm}$, changed seasonally due to their offshore migration during the spawning season (from late summer to early winter). However, they usually showed a greater preference for polyhaline areas and strongly avoided freshwater sites. Euhaline areas were also avoided in autumn and summer. These results suggest that the young of this species are highly dependent on low salinity areas, and any factor that reduces the availability of such areas will, in turn, affect their fishery. Adults depend on polyhaline areas, 
although the avoidance of freshwater regions might be due to their shallowness.

Table (5): Mean \pm standard error (SE) of initial and final body weight (BW), weight gain specific growth rate (SGR), and survival rate of flathead grey mullet (Mugil cephalus) fingerlings as affected with dietary crude protein levels $(24$, and $20 \%)$ with starch ratios $60 \%$ of daily diet under different salinities.

\begin{tabular}{|c|c|c|c|c|c|c|}
\hline \multirow{2}{*}{$\begin{array}{l}\text { Protein } \\
\text { levels\% } \\
\text { and60\% } \\
\text { starch }\end{array}$} & \multirow{2}{*}{$\begin{array}{l}\text { Kind of } \\
\text { water }\end{array}$} & Initial BW & Final BW & Gain & SGR & Survival \\
\hline & & (g) & (g) & (g) & $(\% / d)$ & $\%$ \\
\hline \multirow[t]{3}{*}{24} & Marine & $10.86 \pm 0.10^{\mathrm{a}}$ & $24.27 \pm 0.04^{\mathrm{b}}$ & $13.16 \pm 0.14^{\mathbf{b}}$ & $1.130 \pm 0.01^{\mathrm{b}}$ & $91.26 \pm 1.58^{\mathrm{b}}$ \\
\hline & Brackish & $10.75 \pm 0.07^{\mathrm{a}}$ & $24.25 \pm 0.12^{b}$ & $13.37 \pm 0.09^{\mathrm{ab}}$ & $1.146 \pm 0.01^{\mathrm{a}}$ & $95.23 \pm 1.37^{\mathrm{a}}$ \\
\hline & Fresh & $10.9 \pm 0.13^{\mathrm{a}}$ & $24.37 \pm 0.06^{\mathrm{a}}$ & $13.46 \pm 0.20^{\mathrm{a}}$ & $1.149 \pm 0.02^{\mathrm{a}}$ & $91.27 \pm 4.19^{\mathrm{b}}$ \\
\hline \multirow[t]{3}{*}{20} & Marine & $10.95 \pm 0.066^{\mathrm{a}}$ & $24.2 \pm 0.16^{\mathrm{b}}$ & $13.25 \pm 0.22^{\mathbf{b}}$ & $1.130 \pm 0.01^{\mathrm{b}}$ & $91.27 \pm 4.82^{\mathrm{b}}$ \\
\hline & Brackish & $10.94 \pm 0.156^{\mathrm{a}}$ & $24.24 \pm 0.17^{\mathrm{b}}$ & $13.29 \pm 0.02^{\mathrm{ab}}$ & $1.130 \pm 0.01^{b}$ & $94.44 \pm 1.58^{\mathrm{a}}$ \\
\hline & Fresh & $10.95 \pm 0.126^{\mathrm{a}}$ & $24.45 \pm 0.05^{\mathrm{a}}$ & $13.50 \pm 0.09^{\mathrm{a}}$ & $1.148 \pm 0.01^{\mathrm{a}}$ & $91.27 \pm 2.86^{\mathrm{b}}$ \\
\hline \multicolumn{7}{|c|}{ Pooled means } \\
\hline 24 & & $10.83 \pm 0.00^{\mathbf{h}}$ & $24.21 \pm 0.00^{\mathbf{h}}$ & $13.33 \pm 0.00 \mathrm{~g}$ & $1.14 \pm 0.00 \mathrm{~g}$ & $92.59 \pm 0.17 \mathrm{~g}$ \\
\hline \multirow[t]{4}{*}{20} & & $10.94 \pm 0.00 \mathrm{~g}$ & $24.29 \pm 0.00^{\mathrm{g}}$ & $13.35 \pm 0.00 \mathrm{~g}$ & $1.14 \pm 0.00^{\mathrm{g}}$ & $92.32 \pm 0.02^{\mathbf{h}}$ \\
\hline & Marine & $10.90 \pm 0.21 x$ & $24.43 \pm 0.47 x$ & $13.20 \pm 0.25^{\mathrm{z}}$ & $1.130 \pm 0.02^{\gamma}$ & $91.26 \pm 1.80^{\gamma}$ \\
\hline & Brackish & $10.84 \pm 0.21^{\gamma}$ & $24.24 \pm 0.57 \gamma$ & $13.33 \pm 0.26^{\gamma}$ & $1.138 \pm 0.02^{\mathrm{Y}}$ & $94.83 \pm 1.86 x$ \\
\hline & Fresh & $10.92 \pm .21 x$ & $24.41 \pm 0.07 x$ & $13.48 \pm 0.26^{x}$ & $1.148 \pm 0.05 \chi$ & $91.27 \pm 0.80^{\gamma}$ \\
\hline
\end{tabular}

Means within each comparison in the same column with different superscript differ significantly $(\mathrm{P}<0.05)$.

Similar results had been reported by Barman et al. (2005) when they had implemented two experiments to investigate the effect of inland water salinity on growth performance, feed conversion efficiency, and intestinal enzyme activity in grey mullet. In the experiment I, a 90-day monoculture of grey mullet at different salinity levels $(0,10,15,20$, and $25 \%)$ was carried out. The fingerlings were stocked at 5000 per hectare and fed on a supplementary diet at $5 \% \mathrm{BW} \mathrm{d}-1$. This study revealed that fish growth means bodyweight $(90.5 \pm 4.5 \mathrm{~g})$ and mean length $(21.6 \pm 0.4 \mathrm{~cm})$, SGR $(4.70 \%)$, and growth per day $(0.99 \mathrm{~g} \mathrm{~d}-1)$ were significantly $(\mathrm{P}<0.05)$ enhanced in fish maintained at $10 \%$ salinity in comparison with other treatments. Nutrient levels, phytoplankton population, NPP, and chlorophyll all decreased with increased salinity (>10\%). In addition, zooplankton populations went up with an increase in the salinity level. Most of the other hydrochemical characteristics remained at optimal levels in all other treatments. Fish weight gain showed a significant positive correlation with productivity indicating parameters viz. Also, they stated that significant $(p<0.05)$ high growth, $($ SGR and per cent increase in 
body weight), feed conversion efficiency and intestinal enzyme activity were observed in the group maintained at 10\% salinity in the second experiment (Experiment II), when mullet fry were exposed to five different salinity levels $(10,15,20,25$ and 30\%) and maintained for 70 days in the laboratory, and carcass composition, muscle and liver glycogen levels were also significantly $(\mathrm{P}<0.05)$ affected by salinity changes.

The comparison between habitat availability and habitat use showed that the distribution of all grey mullet species in the estuaries of Minorca was strongly affected by salinity. M. cephalus and L. ramada are good osmoregulators as they maintain a stable internal osmolality in a wide range of external salinity levels, including freshwater (Thomas, 1984; Kulikova et al., 1989). In these two species, the cost of osmotic regulation is the lowest within the oligomesohaline range (Cardona, 1994, 2000). Therefore, the growth is expected to be the highest within that range, although experimental evidence is available only for M. cephalus (Cardona, 2000). Thus, it is not surprising to find out that these two species showed a strong preference for sites with a salinity level under 15, although adults may prefer more saline areas (Cardona, 2000; Chang et al., 2004). However, Chang et al. (2004) revealed individual differences in the habitat preference of $M$. cephalus in Taiwan, as most specimens avoid freshwater sites throughout their life, whereas others spend long periods there.

Generally, it can be concluded that the growth parameters for flathead grey mullet have improved in all salinities under BFT conditions. These results agree with the finding (Burford et al., 2003), who suggested that adding starch helps develop and control dense heterotrophic microbial biofloc in the water column. The BFT conditions in freshwater showed superiority over BFT in marine water because the cost of osmoregulation is the lowest compared to marine water, and this available metabolic energy is used for growth.

\section{Survival rate and condition factor $(K)$}

Survival was high in all treatments. It was above $91 \%$ under BFT conditions at the three salinities (<1ppt, 15.5ppt, and underground marine water). Similar survival rates had been recorded for shrimp under biofloc system by Krummenauer et al. (2011) and Otoshi et al. (2009), who reported that survival ranging from 82.3 to $91.8 \%$ in $75 \mathrm{~m}^{2}$ recirculation aquaculture system stocked at densities ranging from 301 to $408 \mathrm{shrimp} / \mathrm{m}^{2}$.

The condition factor measures the suitability of the environment and food for fish growth and survival (Lagler, 1956). The data reported in Table (6) and (Fig. 3) show the effect of feeding crude protein (24\%, $20 \%$ with $60 \%$ starch) at different salinities under BFT system on the condition factor of $M$. cephalus fingerlings. 
Effect of biofloc system at different salinities and crude protein levels on... Mugil cephalus.

Table (6). Condition Factor values for flathead grey mullet (Mugil cephlus) fed two levels of proteins $(24 \%, 20 \%$ and $60 \%$ starch) under BFT condition in different salinities.

\begin{tabular}{|c|c|c|c|c|c|c|}
\hline \multicolumn{2}{|c|}{ Items } & survival & \multirow[t]{3}{*}{$\begin{array}{l}\text { Initial total } \\
\text { length }\end{array}$} & \multirow[t]{3}{*}{$\begin{array}{l}\text { Condition } \\
\text { factor }\end{array}$} & \multirow[t]{3}{*}{$\begin{array}{l}\text { Final total } \\
\text { length }\end{array}$} & \multirow[t]{3}{*}{$\begin{array}{c}\text { Condition } \\
\text { Factor }\end{array}$} \\
\hline $\begin{array}{l}24, \text { and } \\
20 \% \mathrm{Cp}\end{array}$ & \multirow{2}{*}{$\begin{array}{l}\text { kind of } \\
\text { water }\end{array}$} & \multirow{2}{*}{$\%$} & & & & \\
\hline $\begin{array}{l}\text { Starch } \\
60 \%\end{array}$ & & & & & & \\
\hline \multirow[t]{3}{*}{$24 \mathrm{Cp}$} & Marine & $91.27^{\mathrm{ab}}$ & $10.77 \pm 0.24^{\mathrm{a}}$ & $0.87 \pm 0.06^{\mathbf{a b}}$ & $16.10 \pm 0.26^{\mathrm{a}}$ & $0.58 \pm 0.01^{\mathbf{a b}}$ \\
\hline & Brackish & $95.23^{\mathrm{a}}$ & $10.40 \pm 0.43^{a}$ & $0.97 \pm 0.06^{\mathrm{a}}$ & $15.96 \pm 0.26^{\mathrm{a}}$ & $0.59 \pm 0.03^{\mathrm{ab}}$ \\
\hline & Fresh & $91.27^{\mathrm{ab}}$ & $10.44 \pm 0.46^{a}$ & $0.97 \pm 0.14^{\mathrm{a}}$ & $16.30 \pm 0.52^{\mathrm{a}}$ & $0.56 \pm 0.02^{\mathrm{ab}}$ \\
\hline \multirow[t]{3}{*}{$20 \mathrm{Cp}$} & Marine & $91.27^{\mathrm{ab}}$ & $10.20 \pm 0.32^{\mathrm{a}}$ & $1.04 \pm 0.09^{\mathrm{a}}$ & $15.83 \pm 0.50^{\mathrm{a}}$ & $0.61 \pm 0.02^{\mathrm{a}}$ \\
\hline & Brackish & $94.44^{a}$ & $10.63 \pm 0.26^{\mathrm{a}}$ & $0.91 \pm 0.05^{\mathrm{ab}}$ & $16.26 \pm 0.20^{\mathrm{a}}$ & $0.56 \pm 0.00^{\mathrm{ab}}$ \\
\hline & Fresh & $91.27^{\mathrm{ab}}$ & $10.76 \pm 0.67 \mathrm{a}$ & $0.91 \pm 0.14^{\mathrm{ab}}$ & $15.53 \pm 0.41^{\mathrm{ab}}$ & $0.65 \pm 0.02^{\mathrm{a}}$ \\
\hline \multicolumn{7}{|l|}{$\begin{array}{l}\text { Pooled } \\
\text { means }\end{array}$} \\
\hline $24 \mathrm{CP}$ & & $92.59^{x \gamma}$ & $10.53 \pm 0.37^{\mathrm{x}}$ & $0.93 \pm 0.09^{\gamma}$ & $16.12 \pm 0.34^{\mathrm{x}}$ & $0.57 \pm 0.03^{\mathrm{x}}$ \\
\hline \multirow[t]{4}{*}{$20 \mathrm{CP}$} & & $92.32^{x \gamma}$ & $10.53 \pm 0.41^{\mathrm{x}}$ & $0.95 \pm 0.09^{x}$ & $15.87 \pm 0.36^{x}$ & $0.60 \pm 0.01^{\mathrm{x}}$ \\
\hline & Marine & $91.27 \gamma$ & $10.48 \pm 0.28^{x}$ & $0.95 \pm 0.08^{x}$ & $15.96 \pm 0.25^{\mathrm{x}}$ & $0.59 \pm 0.01^{\mathrm{x}}$ \\
\hline & Brackish & $94.83^{x}$ & $10.51 \pm 0.34^{x}$ & $0.94 \pm 0.05^{x \gamma}$ & $16.11 \pm 0.23^{x}$ & $0.57 \pm 0.01^{\mathrm{x}}$ \\
\hline & Fresh & $91.27 \gamma$ & $10.60 \pm 0.56^{x}$ & $0.94 \pm 0.14^{x \gamma}$ & $15.91 \pm 0.31^{\mathrm{x}}$ & $0.60 \pm 0.02^{x}$ \\
\hline LSD & & 3.45 & 0.81 & 0.18 & 0.82 & 0.4 \\
\hline
\end{tabular}

Means within each comparison in the same column with different superscript differ significantly $(\mathrm{P}<0.05)$.

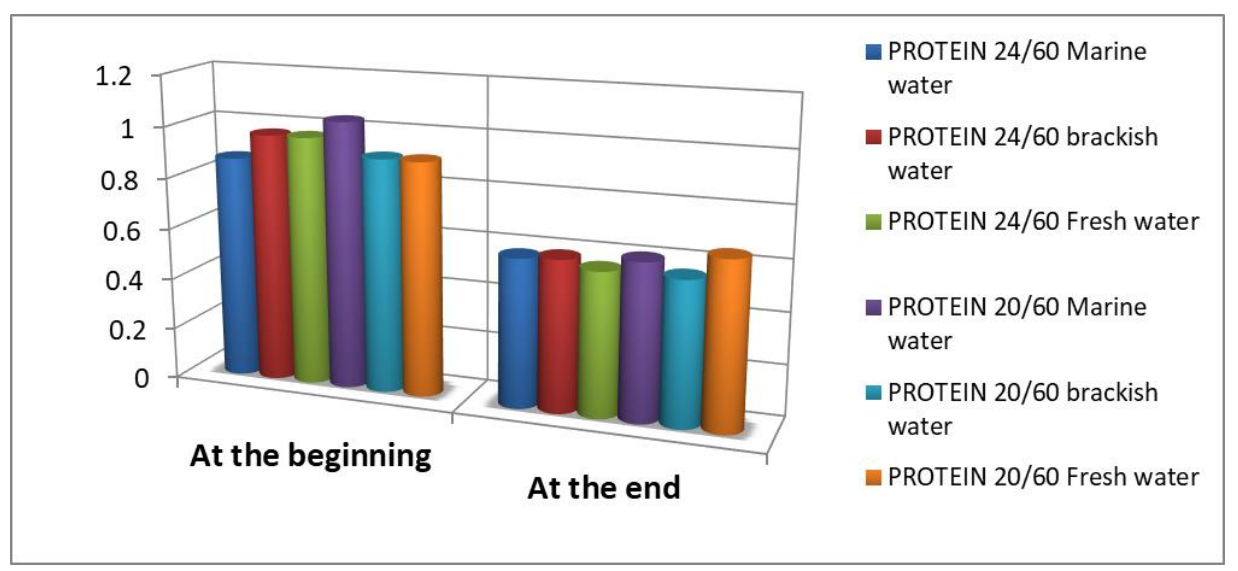

Fig (3): Condition Factor values for flathead grey mullet (Mugil cephlus) fed two levels of proteins $(24 \%, 20 \%$ and $60 \%$ starch) under BFT condition in different salinities. where (MW): marine water, $(\mathrm{B} \mathrm{W})$ : brackish water, $(\mathrm{F} \mathrm{W})$ : fresh water. $(\mathrm{CP})$ : crude protein. 
Data indicated that there are no significant differences between the condition factor of $M$. cephalus fingerlings at the beginning and the end of the experiment; however, the treatment of $(20 \% \mathrm{CP}$ with $60 \%$ starch $)$ in freshwater showed superiority for condition factor at the end $(0.65 \pm 0.02 \mathrm{~g})$ compared to other treatments. Also, the lowest value $(0.56 \pm 0.00 \mathrm{~g})$ was recorded by fish in two treatments (24\% CP with $60 \%$ starch) in freshwater and $(20 \% \mathrm{CP}$ with $60 \%$ starch) in brackish water.

\section{Feed utilization:}

Feed utilization of different treatments is presented in Table (7). Regarding dietary protein, mullet fed (24 and 20\% CP with $60 \%$ starch) under freshwater BFT conditions (C/N 19:1) and (C/N 16:1) showed high values compared to the treatments in marine and brackish water at the same conditions. Both treatments (20\%CP with 60\% starch), and (24\% CP with 60\% starch) under freshwater BFT conditions had similar results in feed intake (FI), FCR, and PER. In comparison, the treatment of (20\% CP with $60 \%$ starch) outperformed the treatment (24\% CP with 60\% starch) in PPV and ER. The same trend was in brackish water and marine water without significant differences, but $\mathrm{CP}$ $20 \%$ showed support for PPV with all salinities.

With no significant differences between all treatments, the best treatment which showed the highest values for feed intake (FI), and feed conversation ratio (FCR), was the treatment (20\% CP with $60 \%$ starch) under freshwater BFT conditions. It also showed the highest values for protein efficiency ratio (PER), and energy retention (ER), but the highest value of protein productive value (PPV) was recorded by the treatment (24\% CP with $60 \%$ starch) under marine water at BFT conditions. Regarding the interaction, mullet fed (20\% CP with $60 \%$ starch) in freshwater under BFT system recorded the highest feed intake FI, PER, ER, and the best FCR values. So we can conclude that feed utilization of the flathead grey mullet fingerlings was improved in all salinities under BFT conditions. Also, freshwater and brackish water showed support for feed utilization parameters compared with marine water under biofloc (BFT) conditions.

These results are close to that recorded by De Silva and Perera (1976) in their experiment which conducted to study the effects of different levels of salinity $(30 \%, 20 \%, 10 \%$ and $<1 \%$ ) on the growth, food intake, and food conversion efficiency of young grey mullet. The daily food intake was found to be very variable at all four experimental salinities, and the intake was found to be salinity-dependent when food was presented in excess. There was no appreciable difference in the growth rate when fed $8 \%$ of the body weight or excess. The percentage conversion efficiency of fish fed on an excess diet at $10 \%$ was the highest. When a constant ratio was given, the percentage conversion efficiency was found to decrease with increasing salinity. 
Table (7). Mean \pm standard error (SE) of offered feed and feed conversion ratio (FCR), protein energy ratio (PER), protein productive value (PPV), and energy retention of flathead grey mullet (Mugil cephalus) fingerlings as affected with dietary crude protein levels $(24,20$ and $60 \%$ starch) with three levels of salinity under BFT conditions.

\begin{tabular}{|c|c|c|c|c|c|c|c|}
\hline \multicolumn{2}{|c|}{$\begin{array}{l}\text { CP 20, 24\% } \\
\text { and 60\% } \\
\text { starch in } \\
\text { different } \\
\text { salinities }\end{array}$} & $\begin{array}{c}\text { Feed } \\
\text { intake }(g)\end{array}$ & Gain (g) & FCR & PER, \% & PPV, \% & $\mathrm{ER}, \%$ \\
\hline \multirow[t]{3}{*}{24} & Marine & $\begin{array}{c}24.87 \pm 0.0 \\
6^{\mathrm{a}}\end{array}$ & $\begin{array}{c}13.16 \pm 0.1 \\
4^{b}\end{array}$ & $\begin{array}{c}1.88 \pm 0.0 \\
1^{\mathrm{a}}\end{array}$ & $\begin{array}{c}2.20 \pm 0.0 \\
1^{\mathrm{a}}\end{array}$ & $\begin{array}{c}36.56 \pm 1.2 \\
5^{\mathrm{a}}\end{array}$ & $\begin{array}{c}66.00 \pm 0.5 \\
7^{b}\end{array}$ \\
\hline & Brackish & $\begin{array}{c}24.60 \pm 0.1 \\
3^{\mathrm{b}}\end{array}$ & $\begin{array}{c}13.37 \pm 0.0 \\
9^{\mathrm{ab}}\end{array}$ & $\begin{array}{c}1.85 \pm 0.0 \\
1^{b}\end{array}$ & $\begin{array}{c}2.24 \pm 0.0 \\
1^{\circ}\end{array}$ & $\begin{array}{c}36.19 \pm 0.8 \\
0^{b}\end{array}$ & $\begin{array}{c}64.65 \pm 0.3 \\
6^{6}\end{array}$ \\
\hline & Fresh & $\begin{array}{c}24.97 \pm 0.0 \\
2^{\mathrm{a}}\end{array}$ & $\begin{array}{c}13.46 \pm 0.2 \\
0^{\mathrm{a}}\end{array}$ & $\begin{array}{c}1.85 \pm 0.0 \\
2^{b}\end{array}$ & $\begin{array}{c}2.24 \pm 0.0 \\
3^{\circ}\end{array}$ & $\begin{array}{c}36.20 \pm 1.9 \\
9^{b}\end{array}$ & $\begin{array}{c}66.46 \pm 0.9 \\
1^{\mathrm{b}}\end{array}$ \\
\hline \multirow[t]{3}{*}{20} & Marine & $\begin{array}{c}24.92 \pm 0.0 \\
7^{\mathrm{a}}\end{array}$ & $\begin{array}{c}13.25 \pm 0.2 \\
2^{b}\end{array}$ & $\begin{array}{c}1.88 \pm 0.0 \\
3^{\mathrm{a}}\end{array}$ & $\begin{array}{c}2.21 \pm 0.0 \\
4^{\mathrm{a}}\end{array}$ & $\begin{array}{c}43.00 \pm 2.5 \\
7^{\mathrm{a}}\end{array}$ & $\underset{\mathrm{e}}{56.7 \pm 1.09}$ \\
\hline & Brackish & $\begin{array}{c}24.81 \pm 0.0 \\
4^{\text {ab }}\end{array}$ & $\begin{array}{c}13.29 \pm 0.0 \\
2^{\mathrm{a}^{\mathrm{b}}}\end{array}$ & $\begin{array}{c}1.86 \pm 0.0 \\
0^{\text {ab }}\end{array}$ & $\begin{array}{c}2.22 \pm 0.0 \\
0^{\mathrm{a}}\end{array}$ & $\begin{array}{c}43.04 \pm 0.1 \\
8^{\mathrm{a}}\end{array}$ & $\begin{array}{c}61.56 \pm 0.0 \\
5^{d}\end{array}$ \\
\hline & Fresh & $\begin{array}{c}24.96 \pm 0.0 \\
2^{\mathrm{a}}\end{array}$ & $\begin{array}{c}13.50 \pm 0.0 \\
9^{\mathrm{a}}\end{array}$ & $\begin{array}{c}1.84 \pm 0.0 \\
1^{b}\end{array}$ & $\begin{array}{c}2.24 \pm 0.0 \\
1^{2}\end{array}$ & $\begin{array}{c}43.71 \pm 0.9 \\
8^{\mathrm{a}}\end{array}$ & $\begin{array}{c}69.03 \pm 0.4 \\
4^{\mathrm{a}}\end{array}$ \\
\hline \multicolumn{8}{|c|}{ Pooled means } \\
\hline 24 & & $\underset{h}{24.80 \pm 0.00}$ & $\begin{array}{c}13.33 \pm 0.0 \\
0^{\mathrm{g}}\end{array}$ & $\begin{array}{c}1.86 \pm 0.0 \\
0 \mathrm{~g}\end{array}$ & $\begin{array}{c}2.22 \pm 0.0 \\
0 \mathrm{~g}\end{array}$ & $\begin{array}{c}36.31 \pm 0.1 \\
1^{\mathrm{g}}\end{array}$ & $\begin{array}{c}65.71 \pm 0.0 \\
5^{\mathrm{g}}\end{array}$ \\
\hline \multirow[t]{4}{*}{20} & & $\begin{array}{c}24.90 \pm 0.00 \\
\mathbf{g}\end{array}$ & $\begin{array}{c}13.35 \pm 0.0 \\
0^{\mathbf{g}}\end{array}$ & $\begin{array}{c}1.86 \pm 0.0 \\
0^{\mathrm{g}}\end{array}$ & $\begin{array}{c}2.22 \pm 0.0 \\
0 \mathrm{~g}\end{array}$ & $\begin{array}{c}43.25 \pm 0.1 \\
1 \mathrm{~h}\end{array}$ & $\begin{array}{c}62.43 \pm 0.2 \\
1 \mathrm{~h}\end{array}$ \\
\hline & Marine & $\begin{array}{c}24.89 \pm 0.06 \\
x\end{array}$ & $\begin{array}{c}13.20 \pm 0.2 \\
5^{2}\end{array}$ & $\begin{array}{c}1.88 \pm 0.0 \\
1^{x}\end{array}$ & $\begin{array}{c}2.20 \pm 0.0 \\
4^{z}\end{array}$ & $\begin{array}{c}39.78 \pm 2.8 \\
7 x\end{array}$ & $\begin{array}{c}61.35 \pm 1.2 \\
1^{z}\end{array}$ \\
\hline & Brackish & $\underset{v}{24.70 \pm 0.48}$ & $\begin{array}{c}13.33 \pm 0.2 \\
6^{v}\end{array}$ & $\begin{array}{c}1.85 \pm 0.0 \\
0^{v}\end{array}$ & $\begin{array}{c}2.23 \pm 0.0 \\
4^{v}\end{array}$ & $\begin{array}{c}39.61 \pm 2.8 \\
0^{2}\end{array}$ & $\begin{array}{c}63.10 \pm 1.2 \\
4^{v}\end{array}$ \\
\hline & Fresh & $\begin{array}{c}24.96 \pm 0.01 \\
2^{x}\end{array}$ & $\begin{array}{c}13.48 \pm 0.2 \\
6^{x}\end{array}$ & $\begin{array}{c}1.84 \pm 0.0 \\
3^{z}\end{array}$ & $\begin{array}{c}2.24 \pm 0.0 \\
2^{x}\end{array}$ & $\begin{array}{c}39.95 \pm 2.8 \\
6^{v}\end{array}$ & $\begin{array}{c}67.74 \pm 1.3 \\
3^{x}\end{array}$ \\
\hline
\end{tabular}

Means within each comparison in the same column with different superscript differ significantly $(\mathrm{P}<0.05)$.

Similar results were recorded where Barman et al. (2005) found that fish weight gain showed a significant positive correlation with productivity at $<10 \%$ salinity. Also, they stated that significantly $(\mathrm{P}<0.05)$ feed conversion efficiency and intestinal enzyme activity were observed in the group maintained at $10 \%$ salinity when mullet fry was exposed to five different salinity levels $(10,15,20,25$, and $30 \%)$ and maintained for 70 days in the laboratory. 
The same thing had been confirmed by De Silva and Perera (1978) in their study on yearling Pufferfish, where the study included the effect of salinity on food intake, growth, food conversion ratio, and survival. Within the salinity regimes of 0 (freshwater), 8,18 , and 35 , the food intake levels were $0.97 \%$, $1.43 \%, 1.19 \%$, and $1.01 \%$, respectively; and food conversion ratios were 1.31 , $1.93,1.61$, and 1.36 , respectively. The data series was reduced with increasing salinity. However, the survival rates did not show the same tendencies, which were $80 \%, 100 \%, 100 \%$, and $67 \%$, respectively. There were significant differences among the treatments. In conclusion, the yearling Pufferfish optimal culture salinity condition was about $8.0 \mathrm{ppt}$, but they also cited the opposite with young grey mullet in De Silva and Perera (1978), when they carried out an experiment to study the effect of body size and salinity on the rate of digestion of young grey mullet, Mugil cephalus L., it had been performed using the "sacrifice" method. The digestion rate was found to be salinity-dependent, being slower at lower salinities than at higher salinities. This is correlated to higher food intake at the lower salinities. The digestion rate was also found to be dependent on body size, increasing with increasing body weight (Borges et al., 2020).

\section{Body composition}

The whole-body chemical composition of flathead grey mullet ( $M$. cephalus) fingerlings are summarized in Table (8). Although there are no substantial differences in mullet chemical composition reared at different salinities under BFT system, mullet protein and ash content increased with marine water BFT conditions under crude protein $24 \%$ and $20 \%$, respectively. The opposite was reported for dry matter and lipids, as it was increased in brackish water and freshwater, respectively. These observations agree with (Abedel-Tawab et al., 2006; Borges et al., 2020), who reported that the changes in protein and lipid content in fish body could be linked with changes in their synthesis and/or deposition rate in the muscle.

The bio-flocs' chemical analysis in this experiment showed that the crude protein contents differ significantly with a range of $35.97-38.13 \%$, but it was high in all salinities, Table (9). This suggested that there was no effect of salinity on the crude protein content of the bio-flocs. Regardless of the origin of bioflocs inoculums (freshwater tilapia farm), similarity in the crude protein content, as well as other parameters (crude lipid, fatty acids profile and ash content) in different salinity tested, was expected, as several studies showed that salinity has no direct effect on the bacterial growth and it was assumed that increased or lowered salinity would select for new physiological types that are able to tolerate the given salt levels while possessing the same metabolic capabilities (Del Giorgio and Cole 1998; Nielsen et al. 2003). 
Table (8): Mean \pm standard error (SE) of chemical composition of flathead grey mullet (Mugil cephalus) fingerlings as affected with dietary crude protein levels (24, 20 and $60 \%$ starch) with three levels of salinity under BFT system.

\begin{tabular}{|c|c|c|c|c|c|}
\hline $\begin{array}{l}\text { CP Levels } \\
\text { and } 60 \% \\
\text { starch }\end{array}$ & $\begin{array}{l}\text { Kind of } \\
\text { water }\end{array}$ & Dry Matter, $\%$ & Protein, $\%$ & Fat, \% & Ash, $\%$ \\
\hline \multirow[t]{3}{*}{24} & Marine & $27.29 \pm 0.00^{\mathrm{a}}$ & $64.32 \pm 0.25^{\mathrm{a}}$ & $19.55 \pm 0.30^{\mathrm{ab}}$ & $15.25 \pm 0.20^{\mathrm{d}}$ \\
\hline & Brackish & $27.56 \pm 0.00^{\mathrm{a}}$ & $63.76 \pm 0.25^{\mathrm{b}}$ & $19.83 \pm 0.20^{\mathrm{a}}$ & $15.62 \pm 0.41^{\mathrm{c}}$ \\
\hline & Fresh & $27.15 \pm 0.00^{\mathrm{ab}}$ & $63.87 \pm 0.13^{\mathrm{b}}$ & $19.64 \pm 0.17^{\mathrm{ab}}$ & $15.16 \pm 0.10^{\mathrm{d}}$ \\
\hline \multirow[t]{3}{*}{20} & Marine & $27.24 \pm 0.00^{\mathrm{a}}$ & $64.04 \pm 0.32^{\mathrm{ab}}$ & $17.36 \pm 1.10^{\mathrm{d}}$ & $18.28 \pm 0.09^{\mathrm{a}}$ \\
\hline & Brackish & $27.11 \pm 0.00^{\mathrm{ab}}$ & $63.97 \pm 0.25^{\mathrm{ab}}$ & $18.83 \pm 0.36^{\mathrm{c}}$ & $16.75 \pm 0.36^{b}$ \\
\hline & Fresh & $27.45 \pm 0.00^{\mathrm{a}}$ & $63.91 \pm 0.15^{\mathrm{b}}$ & $19.02 \pm 0.92^{\mathrm{b}}$ & $15.49 \pm 0.66^{\mathrm{c}}$ \\
\hline \multicolumn{6}{|l|}{ Pooled means } \\
\hline 24 & & $27.33 \pm 0.00 \mathrm{~g}$ & $63.98 \pm 0.01^{\mathrm{g}}$ & $19.67 \pm 0.01^{\mathrm{g}}$ & $15.34 \pm 0.01^{\mathbf{h}}$ \\
\hline \multirow[t]{4}{*}{20} & & $27.26 \pm 0.00 \mathrm{~g}$ & $63.97 \pm 0.01^{\mathrm{g}}$ & $18.57 \pm 0.06^{\mathbf{h}}$ & $17.08 \pm 0.05 \mathrm{~g}$ \\
\hline & Marine & $27.26 \pm 0.53 x$ & $64.36 \pm 1.26^{x}$ & $18.45 \pm 0.36^{\mathrm{z}}$ & $16.76 \pm 0.13^{x}$ \\
\hline & Brackish & $27.23 \pm 0.53 x$ & $63.86 \pm 1.25^{\mathrm{Y}}$ & $19.33 \pm 0.38^{\mathbf{Y}}$ & $16.18 \pm 0.32^{x}$ \\
\hline & Fresh & $27.30 \pm 0.53 x$ & $63.89 \pm 1.25^{\mathrm{Y}}$ & $19.66 \pm 0.38^{x}$ & $15.32 \pm 0.30^{\mathrm{Y}}$ \\
\hline
\end{tabular}

Means within each comparison in the same column with different superscript differ significantly $(\mathrm{P}<0.05)$.

The average crude protein content of the bio-flocs in saline water was $36 \%$, and it was in correspondence with other studies in saline water, where the protein content was in the range of 32 to $38 \% \mathrm{DW}$ (Ju et al. 2008). The average crude protein content of the bio-flocs in brackish water was $37 \%$ DW. The average crude protein content of the bio-flocs in freshwater was $38 \% \mathrm{DW}$; it was similar to Vanstechelman (2008) and Ekasari (2010) studies, which were 33 to 37\%DW. Also, Ekasari (2010) concluded that there was no effect of carbon source and salinity on the content of crude protein and lipid in bio-flocs. The crude lipid content in this study ranged from 7 to $9 \%$ on the DW. This was higher than that in other studies, where it ranged from 2 to $2.5 \%$ on the DW in freshwater (Azim et al. 2007) and 1.2 to $2.6 \%$ on the DW in marine water (Tacon et al. 2002; Ju et al. 2008). Salinity, as well as carbon source, did not affect the crude lipid content of the bio-flocs. Russel et al. (1995) suggested that one of the major osmoregulatory responses to salt concentration in bacteria is altering the membrane lipid composition.

The average ash content was in the range of $8-13 \%$ on the DW, which agrees with other studies, where the ash content ranged from 7 to $32 \%$ on the DW (Tacon et al., 2002; Azim et al., 2007; Ju et al. 2008). Furthermore, Tacon et 
al. (2002) suggested that the high ash content in the bio-flocs probably should be related to the presence of acid-insoluble oxides and mixed silicates. It is also suggested that bio-flocs are a good source of essential minerals and trace elements (Tacon et al., 2002).

Table (9): Mean \pm standard error (SE) of chemical composition of biofloc in the same column with different superscript are significantly different $(\mathrm{P}<0.05)$.

\begin{tabular}{|c|c|c|c|c|}
\hline $\begin{array}{l}\text { CP levels\% } \\
\text { and } 60 \% \text { starch }\end{array}$ & $\begin{array}{l}\text { Kind of } \\
\text { Water }\end{array}$ & Protein, $\%$ & Fat, \% & Ash, \% \\
\hline \multirow[t]{3}{*}{24} & Marine & $36.00 \pm 0.23^{\mathrm{c}}$ & $7.16 \pm 0.17^{\mathrm{c}}$ & $8.53 \pm 0.17^{c}$ \\
\hline & Brackish & $37.08 \pm 0.37^{\mathbf{b}}$ & $7.53 \pm 0.17^{b}$ & $12.76 \pm 0.75^{\mathrm{a}}$ \\
\hline & Fresh & $38.13 \pm 0.14^{a}$ & $9.05 \pm 0.45^{\mathrm{a}}$ & $10.58 \pm 0.39^{b}$ \\
\hline \multirow[t]{3}{*}{20} & Marine & $35.97 \pm 0.34^{\mathrm{c}}$ & $7.13 \pm 0.08^{c}$ & $8.03 \pm 0.12^{\mathrm{c}}$ \\
\hline & Brackish & $37.11 \pm 0.12^{b}$ & $7.16 \pm 0.17^{b}$ & $12.96 \pm 0.18^{\mathrm{a}}$ \\
\hline & Fresh & $37.99 \pm 0.19^{\mathrm{a}}$ & $8.96 \pm 0.07^{\mathrm{a}}$ & $11.03 \pm 0.20^{\mathrm{b}}$ \\
\hline \multicolumn{5}{|l|}{ Pooled means } \\
\hline 24 & & $37.07 \pm 0.03 \mathrm{~g}$ & $7.91 \pm 0.03^{\mathrm{g}}$ & $10.62 \pm 0.07 \mathrm{~g}$ \\
\hline \multirow[t]{4}{*}{20} & & $37.02 \pm 0.03 \mathrm{~g}$ & $7.75 \pm 0.03 \mathrm{~g}$ & $10.67 \pm 0.08^{\mathrm{g}}$ \\
\hline & Marine & $35.98 \pm 0.70^{x}$ & $7.14 \pm 0.13^{\gamma}$ & $5.52 \pm 0.16^{\gamma}$ \\
\hline & Brackish & $37.09 \pm 0.72^{\gamma}$ & $7.34 \pm 0.14^{\gamma}$ & $5.57 \pm 0.25^{\gamma}$ \\
\hline & Fresh & $38.06 \pm 0.74 x$ & $9.00 \pm 0.17 x$ & $7.20 \pm 0.21 x$ \\
\hline
\end{tabular}

Means within each comparison in the same column with different superscript differ significantly $(\mathrm{P}<0.05)$

\section{Economic efficiency and evaluation}

The calculation of the tested diet's economic efficiency based on the cost of feed cost of one $\mathrm{kg}$ weight gain is shown in table (10). The diet of (20\% CP and $60 \%$ starch) under BFT system with freshwater was the lowest in the total cost and the highest in total return. As described in this table feed, cost per kg gain (LE) fed 24\% CP and 20\% CP with 60\% starch in different salinities (fresh, brackish, and marine) water under BFT system. Table (10) showed that the diet of $20 \% \mathrm{CP}$ with $60 \%$ starch in freshwater was the lowest in the relative feed cost $/ \mathrm{kg}$ compared to the other diets. So, the rearing of flathead grey mullet fingerlings with crude protein level $20 \%$ and starch level $60 \%$ from daily diet seemed to be economical at (Mugil Cephalus) fingerlings. 
Table (10): Cost of feed required for producing one $\mathrm{Kg}$ gain of $M$ cephalus fingerlings as reared in different salinities under BFT conditions.

\begin{tabular}{|l|c|c|c|c|}
\hline \multicolumn{1}{|c|}{ Treatments } & $\begin{array}{c}\text { Feed cost } \\
\text { per kg }\end{array}$ & FCR & $\begin{array}{c}\text { Cost/kg } \\
\text { fresh fish }\end{array}$ & $\begin{array}{c}\text { Relative } \\
\text { feed cost/kg }\end{array}$ \\
\hline $\begin{array}{l}\text { 24\% CP+60\% starch } \\
\text { (Marine water) }\end{array}$ & 4.29 & 1.88 & 4.39 & 111.9 \\
\hline $\begin{array}{l}\text { 24\% CP+60\% starch } \\
\text { (brackish water) }\end{array}$ & 4.29 & 1.85 & 4.26 & 108.6 \\
\hline $\begin{array}{l}\text { 24\% CP+60\% starch (fresh } \\
\text { water) }\end{array}$ & 4.30 & 1.85 & 4.29 & 109.4 \\
\hline $\begin{array}{l}\text { 20\% CP+60\% starch } \\
\text { (Marine water) }\end{array}$ & 3.88 & 1.88 & 3.96 & 101 \\
\hline $\begin{array}{l}\text { 20\% CP+60\% starch } \\
\text { (brackish water) }\end{array}$ & 3.87 & 1.86 & 3.96 & 101 \\
\hline $\begin{array}{l}\text { 20\% CP+60\% starch (fresh } \\
\text { water) }\end{array}$ & 3.87 & 1.84 & 3.92 & 100 \\
\hline
\end{tabular}

Relative feed cost $/ \mathrm{kg}$ fresh fish $=\frac{\text { Values of feed cost } / \mathrm{kg} \text { fresh } \mathrm{fish}}{\text { The minimum value of ths same parameter }}$

\section{Conclusion:}

Depending on the obtained results, it could be concluded that mullet fed $20 \% \mathrm{CP}$ with $60 \%$ starch or $(\mathrm{C} / \mathrm{N}, 19: 1)$ under freshwater BFT conditions recorded the best fish performance, feed utilization, water quality, and total account of zooplankton and phytoplankton.

\section{REFERENCES}

Abdel-Hafez, S. M. and El-Kryony, E. A. (1992). Operating economics of the current project of fish cages in Damietta Governorate. Bulletin of Science and Development Research, 38: 570.

AOAC. (1995). Official Methods of Analysis, 15th ed. Association of Official Analytical Chemists, Arlington, VA.

AOAC. (2000). Official Methods of Analysis, 15th edition, Washington, DC; USA.

Avnimelech, Y. (2009). Biofloc Technology - A Practical Guide Book. The World Aquaculture Society, Baton Rouge, Louisiana, United States. 182 pp.

Avnimelech, Y; and Kochba, M. (2009). Evaluation of nitrogen uptake and excretion by tilapia in bio floe tanks, using N15 tracing. Aquaculture, 287:163-168. 
Azim, M. E; Little, DC; and North, B. (2007). Growth and welfare of Nile tilapia (Orechromis niloticus) cultured in indoor tanks using biofloc technology (BFT). Aquaculture.

Bartholomew, G; and Kevin K. S. (2013). Effect of initial biomass on Channel Catfish yield and water quality in a biofloc technology Production System. World Aquaculture Society Meetings. Saturday, February 23rd.

Barman, U. K; Jana , S. N; Garg, S. K; Bhatnagar, A; and Arasu, A.R.T. (2005) Effect of inland water salinity on growth, feed conversion efficiency and intestinal enzyme activity in growing grey mullet, Mugil cephalus (Linn.): Field and laboratory studies. Aquaculture International . (13). pp 241-256.

Ben Tuvia, A; Davidoff, E.B; Shapiro, J; and Shefler. D. (1992). Biology and management of lake Kinneret fisheries. Israel. J. Aquaculture-Bamidgeh, 44: 48-65.

Borgesa, B. A. A; Rochaa, J. L; Pintoa, P H. O; Zacheua ; Chedea, A. C; Magnottib, C. C. F; Cerqueirab, V. R. and Arana, L. A. V. (2020). Integrated culture of white shrimp Litopenaeus vannamei and mullet Mugil liza on biofloc technology: Zootechnical performance, sludge generation, and Vibrio spp. Reduction. Aquaculture 524 (2020) 735234. https://doi.org/10.1016/j.aquaculture.2020.735234

Braga, A; Magalhaes, V; Timothy C; Bob Advent, M; and Samocha, T. M. (2013). Use of a non-venturi air injection system for production of Litopenaeus Vannamei in biofloc-dominated zero-exchange raceways. World Aquaculture Society Meetings. Saturday, February 23rd.

Burford, M. A.; Thompson, P.J.; Mclntosh, R.P.; Bauman, R.H; and Pearson, D.C. (2003). Nutrient and microbial dynamics in high-intensity, zeroexchange shrimp ponds in Belize. Aquaculture, 219:393-11. Cambridge, NY, USA 388 p.

Cardona, L. (1994). Estructura de las comunidades de mugílidos (Osteichthyes, Mugilidae) en ambientes estuáricos. Doctor of Science thesis, Univ. Barcelona.

Cardona, L. (2000). Effects of salinity on habitat selection and growth of performance Mediterranean flathead grey Mullet Mugil cephalus (Osteichthyes Mugilidae) Eustuarine- costal- and-Shelf-Science, (50).227237.

Chang, C.W; Iizuka Y; and Tzeng. WN (2004). Migratory environmental history of the grey mullet Mugil cephalus as revealed by otholit Sr:Ca ratios. Mar. Ecol. Prog. Ser., 269: 277-288. 
Crab, R. (2010). Bioflocs technology: an integrated system for the removal of nutrients and simultaneous production of feed in aquaculture. $\mathrm{PhD}$ thesis, Ghent University. 178 pp.

Del Giorgio P; Cole, J. J. (1998). Bacterial growth efficiency in natural aquatic systems. Annu Rev Ecol Sys 29:503-541.

De Silva, S.S; and Perera, P.A.B. (1976). Studies on the young grey mullet, Mugil cephalus L.: I. Effects of salinity on food intake, growth and food conversion. Aquqculture. (7) . 327-338

De Silva, S.S; and Perera, P.A.B. (1978). Effects of salinity on the food intake, growth, food conversion ratio and survival of yearling puffer fish (Fugu obscurus). Marine Biology. ( 6) :645-658.

Ebeling, J.M.; Timmons, M.B; and Bisogni, J. J. (2006). Engineering analysis of the stoichiometry of photo autotrophic, autotrophic, and heterotrophic removal of ammonia-nitrogen in aquaculture systems. Aquaculture, 257: 346-358.

Ekasari, J; Crab, R; Verstraete. W. (2010). Primary Nutritional content of bioflocs cltured with different organic carbon sources and salinity. HAYATI Journal of Biosciences. Vol. 17 No. 3, p 125-130.

El-Dahhar, A. A; Salama, M; Elebiary, E. H; Abo El-Wafa. M. A; and Ghazy, A. I. (2015). Effect of Energy to Protein Ratio in Biofloc Technology on Water Quality, Survival and Growth of Mullet (Mugil cephalus). Journal of the Arabian Aquaculture Society. Vol. 10 No 1, June 2015. DOI: 10.12816/0026633

Elhetawy A. I. G; Vasilyeva. L. M; Lotfy. A. M; Emelianova. N; AbdelRahim. M. M; Helal. A. M; and Sudakova. N. V. (2020). Effects of the rearing system of the Russian sturgeon (Acipenser gueldenstaedtii) on growth, maturity, and the quality of produced caviar. AACL Bioflux 13(6):3798-3809.

Essa, M. A. (2010). Present status of aquaculture in Egypt. In: Joint workshop on sustainable Development of Aquaculture in Egypt: Prospects, Challenges and Solution. National Inst. Oceanography and fisheries in Cooperation with the Inst. Aquaculture, Univ. of Stirling, Stirling, Scotland. Alexandria, February 3rd, 2010, Egypt.

FAO (2012). the State of World Fisheries and Aquaculture 2012. Contributing to food security and nutrition for all. Rome, Italy.

FAO (2016). the State of World Fisheries and Aquaculture 2016. Contributing to food security and nutrition for all. Rome, Italy, p. 200.

FAO. (2018). the State of World Fisheries and Aquaculture 2018. Contributing to food security and nutrition for all. Rome, Italy. 
Foissner, W; and Berger, H. (1996). A user-friendly guide to the ciliates (Protozoa, Ciliophora) commonly used by ydrobiologists as bio indicators in rivers, lakes and waste waters with notes on their ecology. Freshwater Biol., 35: 375-482.

GAFRD. (2012). General authority for fish resources development, Report on fish production, Cairo, Egypt.

GAFRD. (2015). General authority for fish resources development, Report on fish production, Cairo, Egypt.

Hargreaves, J. A. (2006). Photosynthetic suspended-growth systems in aquaculture. Aqua cultural Engineering, 34:344-363.

Ju, Z.Y; Forster, L; Conquest, L; Dominy, W; Kuo, W.C; and Horgen, F.D. (2008). Determination of microbial community structures of shrimp floe cultures by biomarkers and analysis of floe amino acid profiles. Aquaculture Research, 39: 118-133.

Krummenauer, D; Peixoto, S; Cavalli, R. O; Poersch, L. H; and Wasielesky. W. (2011). Superintensive culture of white shrimp, Litopenaeus vannamei, in a biofloc technology system in southern Brazil at different stocking densities. Journal of the World Aquaculture Society 42:726-733.

Kulikova, N. I; Shekk, P.V; Starushenko, L.I; and Rudenko, V. I. (1989). Effect of salinity on resistance to low temperatures in the Black sea mullets during early ontogenesis. In: L.A. Dushkina (ed.), Early life history of mariculture species, pp. 81-102. Vniro, Moscow.

Lagler, K.P. (1956). Fresh water fish biologh. WMC Company publication, Dubugue, Iowa.

Manan, H; Amin-Safwan, A; Kasan, N. A; and Ikhwanuddin, M. (2020). Effects of Biofloc Application on Survival Rate, Growth Performance and Specific Growth Rate of Pacific Whiteleg Shrimp, Penaeus vannamei Culture in Closed Hatchery System. Pak. J. Biol. Sci., 23: 1563-1571. https://doi.org/10.3923/PJBS.2020.1563.1571

McDowall, R.M. (1988). Diadromy in fishes. Migrations betweenfreshwater and marine environments. Croom Helm, London.

Naik, M. K; and Reddy, M. S. (2020). Effect of biofloc system on growth performance in shrimp litopenaeus vannamei under different $\mathrm{c}: \mathrm{n}$ ratios with sugarcane molasses. International Journal of Scientific \& Engineering Research Volume 11, Issue 5, May-2020.

Nielsen, D.L; Brock. M. A; Rees. GN; Baldwin. D. S. (2003). Effects of increasing salinity on freshwater ecosystems in Australia. Aus J Bot 51:655665 . 
Otoshi, C. A; Tang, L. R.; Moss, d. R; Arce, S. M; Holl, C. M.; and Moss, S. M. (2009). Performance of Pacific white shrimp, Penaeus (Litopenaeus) vannamei) cultured in biosecure, super-intensive, recirculating aquaculture systems. Pages $244-252$ in C. L. Browdy and D. E. Jory, editors. The Rising Tide - Proceedings of the Special Session on Sustainable Shrimp Farming. The World Aquaculture Society, Baton Rouge, Louisiana, USA.137.

Paerl, H.W; and Tucker, C.S. (1995). Ecology of blue-green algae in aquaculture ponds. J. World Aquacult. Soc. 26, 109-131.

Panigrahi, A; Otta, S. K; Kumaraguru V. K. P; Shyne A. P. S; Biju I. F; and Aravind, R. (2019). Training manual on Biofloc technology for nursery and grow-out aquaculture, CIBA TM series 2019 No. 15, 172 pp.

Pontin, R. M. (1978). A key to the fresh water plankton and semi-plankton Rotifera of the British Isles, 178 pp. Freshwater Biological Association, Scientific Publication 38.

Saleh, M. A. (2008). Capture-based aquaculture of mullets in Egypt. In A. Lovatelli and P.F. Holthus (eds). Capture-based aquaculture. Global overview. FAO Fisheries Technical Paper. No. 508. Rome, FAO. pp. 109126.

Schradera, K. K; Greenb, P. W; and Perschbacherc, P. W. (2011), Development of phytoplankton communities and common off-flavors in a biofloc technology system used for the culture of channel catfish (Ictalurus punctatus). Aquacultural Engineering. (45). pp 118- 126.

Scott, D.C.B; Muir, J.F; and Robertson, D.A. (1993). Feasibility study of tow offshore cage system for the production of sea bream in the Mediterranean. In: Proc. World Aquaculture Society Conf., torremolinos (Spain).

Tacon, A.G.J.; Cody, J.J.;; Conquest, LD; Divakaran, S; Forster, I.P; and DecampP, O.E. (2002). Effect of culture system on the nutrition and growth performance of Pacific white shrimp Litopenaeus vannamei (Boone) fed different diets. Aquaculture Nutrition, 8: 121-

Thomas, P. (1984). Influence of some environmental variables on the ascorbic acid status of mullet, Mugil cephalus L., tissues. I. Effect of salinity, capture-stress and temperature. J. Fish Biol., 25: 711-720.

Vanstechelman, H. (2008). Bio-vloktechnologie: Het verwijderen van nutrienten in de aquacultuur en de simultane productie van hoogwaardige nutritionele vlokken [Thesis]. Ghent, Belgium: Ghent University.

Wallace, R. L; and Snell, T. W. (1991). Rotifera. In Ecology and Classification of North American Freshwater Invertebrates. Academic Press, New York, USA 187 - 248. 
تأثير نظام البيوفلوك في درجات ملوحة مختلفة مع مستويين من البروتين الخام على كلا من جودة المياه ومعدلات نمو الأسماك والإعاشة لأسماك البورة البوري الحر (Mugil cephalus).

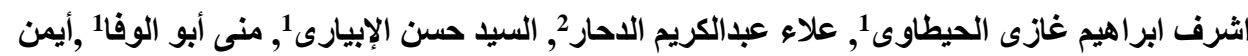
محمد لطفى 1 ناديجدا إميليانوفا3.

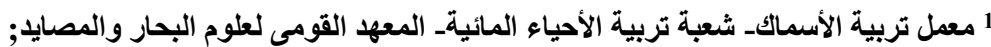

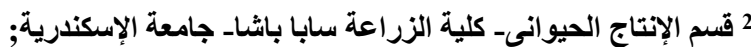
3 قسم الغة الإنجليزية. كلية اللغاتـ جامعة أستراخان العكومية.

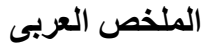

صمعت هذه الدراسة للكثف عن تأثير الملوحة المختلفة لكلا من المياة العذبة(> (15pt),

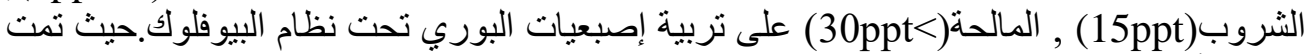

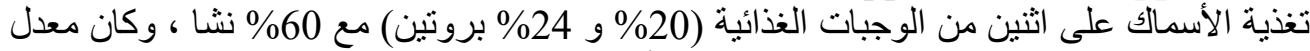

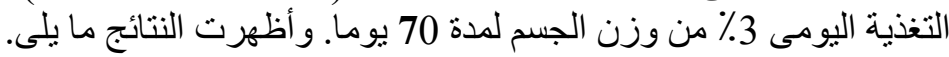





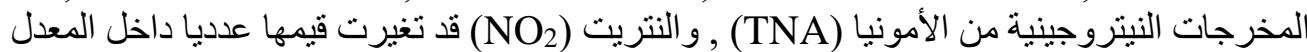
الطبيعي ( تسجل فروقا معنوية لصالح إحدى الملوحات, أما النترات فقد سجلت معدلا أعلى من المعدل الطبيعي في كل المعاملات.

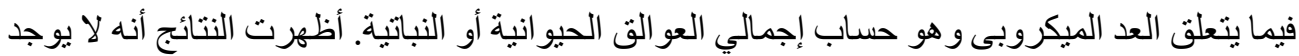







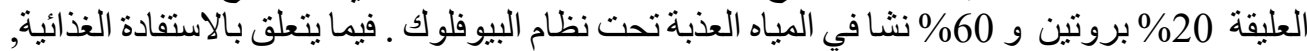

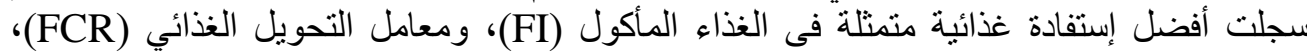

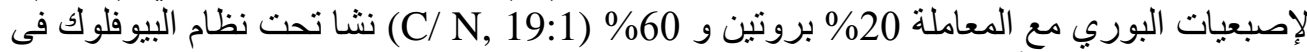

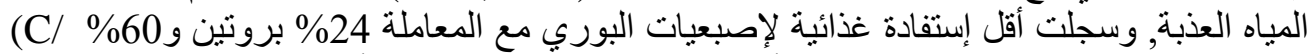

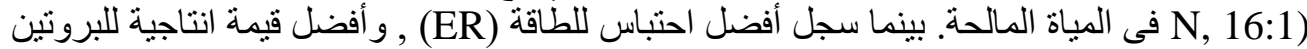

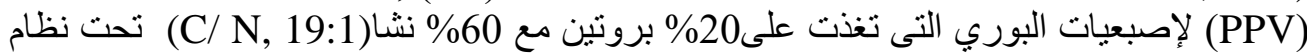

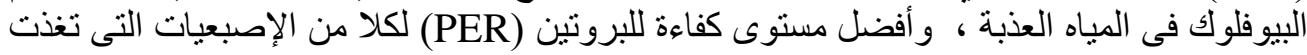

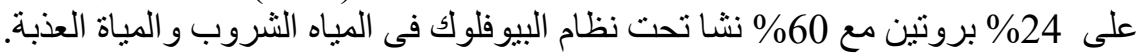

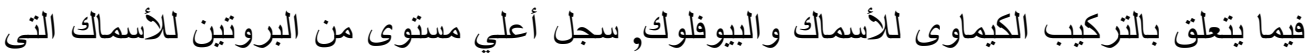

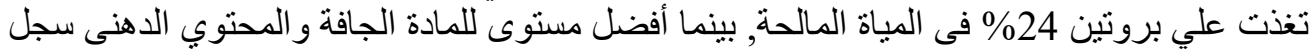



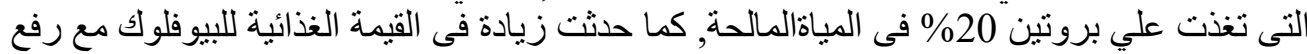

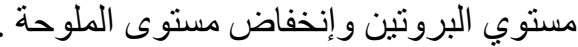

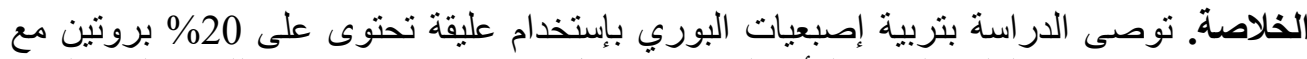

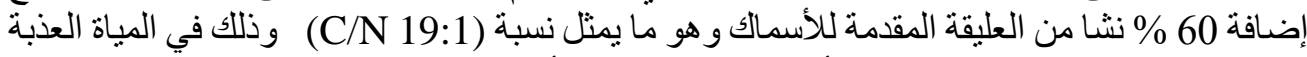

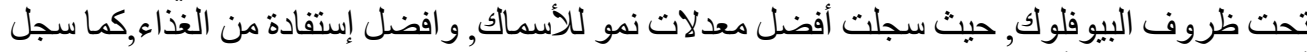
أفضل جودة مياة وأعلى عد ميكروبى. 